\title{
The Organisation of Innovation:
}

\section{Collaboration, Co-operation and Multifunctional Groups in UK and German Manufacturing}

\author{
James H Love \\ Aston Business School, Aston University \\ Birmingham B4 7ET, United Kingdom \\ e-mail: j.h.love@aston.ac.uk \\ Stephen Roper \\ Northern Ireland Economic Research Centre \\ Belfast BT7 1NN, United Kingdom \\ e-mail: s.roper@qub.ac.uk
}

\begin{abstract}
:
Marked differences exist between the institutional and social context for innovation in the UK and Germany. The question addressed here is how these different contexts impact on the objectives and organisation of innovation in UK and German manufacturing. In particular, we examine the extent to which UK and German plants engage in inter-plant collaboration and co-operation and multifunctional working as part of their innovative activity, and explore the reasons for differences in these patterns of involvement. The investigation is based on a large-scale, comparative survey of manufacturing plants in the two countries

In Germany, institutional and social norms are found to encourage collaborative interplant innovation but aspects of the German skills training and industrial relations systems make the adoption of more flexible internal systems more difficult. In the UK on the other hand, the more adversarial nature of inter-firm relations makes it more difficult to establish external collaborations based on mutual trust, but less restrictive labour market structures make it easier for UK plants to adopt multifunctional working. This is linked to differences in attitudes to the property rights and transaction cost problems inherent in innovation.
\end{abstract}

Key words: Organisation, Innovation, Institutions, Property rights

JEL classification: D23, O31 


\section{The Organisation of Innovation: Collaboration, Co-operation and Multifunctional Groups in UK and German Manufacturing}

\section{Introduction}

Economists have long recognised the importance of innovation, the process that connects technological progress with commercial activity and economic growth. Beginning with Adam Smith, classical economic thought allied an understanding of the importance of the fundamental process of technological change with a wealth of observational detail reflecting the institutional and industrial organisation of the time. This tradition extended well into the nineteenth century: Marshall's description of industrial districts, for example, emphasised the importance of institutional and contextual factors in encouraging innovation as well as the rapid dissemination and adoption of new techniques and technologies. Subsequently, much of the observational richness and institutional perspective implicit in this approach was lost in the neo-classical search for universal and testable predictions. Recent work undertaken primarily by economic geographers and industrial sociologists, however, is recognisably within this tradition and emphasises the importance of the social and institutional context within which technological change takes place.

This recent research suggests several key points. First, although national differences are evident, innovation is typically incremental rather than radical: Audretsch (1995), for example, suggests that almost 90 per cent of commercially significant innovations in the United States are actually incremental in nature, involving the development, application and re-application of existing knowledge with little or no scientific advance. Second, innovation is best understood as a continuous and evolutionary process shaped by institutions, social conventions and the intensity and extent of organisational interactions (Morgan 1997; Grabher and Stark 1997). Third, different national and regional modes of social and industrial organisation, characterised by different institutional structures, regulatory frameworks and social conventions, generate very different innovation outcomes (e.g. Nelson, 1993; Braczyk et al, 1998). This final point is epitomised by debates about the relative merits of the Rhenish and Anglo-Saxon modes of capitalism 
and their ability or inability to adopt new production techniques in response to increasingly global competition (e.g. Dore et al., 1999).

Our aim here is to contribute to this debate using very detailed data which allow us to contrast the organisation of innovation by UK and German manufacturing plants. In particular, we focus on the systemic and institutional influences on: the nature of product innovation undertaken by UK and German plants; the collaborative activities of UK and German manufacturing plants as part of their innovation activity; and the organisation of innovation within UK and German plants (focussing particularly on multifunctional working). The UK-Germany comparison is of particular interest in this respect because of the marked institutional contrasts between the two countries (Dore et al., 1999) epitomised by the high skill equilibrium (HSE) in Germany (e.g. Finegold and Soskice, 1988 ) and the two countries' very different financial and industrial relations systems (Culpepper, 1999). Other, perhaps derivative, differences also exist between the UK and Germany in terms of innovation propensities, national innovation systems (e.g. Keck, 1993; Walker, 1993; Roper et al., 1996), inter-firm labour mobility (Soskice 1997) and economic outcomes (e.g. Anderton, 1999). However, our focus is on one particular aspect of these institutional differences: the effect on the organisation of innovation of different responses to the transaction cost and property rights problems inherent in innovation. The present paper should therefore be seen as the institutional counterpart to a series of econometric studies on the determinants of innovation in UK and German manufacturing (Love and Roper 1999, 2001; Roper et al 2000).

The argument proceeds as follows. In section 2 we outline the received view of the UK and German innovation-production systems and set the institutional context for the main comparison of the organisation of innovation. Section 3 focuses on the nature of manufacturing innovation in the two countries and its consistency with the orthodox view. In sections 4 and 5 the focus shifts to the organisation of innovation activity in the two countries, looking first at inter-plant co-operation and collaboration and then multifunctional working. Section 6 summarises the main empirical findings of the paper and discusses some of the implications. 


\section{Institutional and Contextual Framework}

The German innovation and production system is often characterised as having a focus on diversified quality production (DQP), involving the incremental customisation of products rather than mass production or products derived from radical innovation (Streeck, 1989). "The resulting pattern of innovation is one that is more likely to generate improvements of existing products and sectors than to give rise to new sectors. Generally, sticky decisions, steady commitments and delayed responses in German institutions make for slow fluctuations, up or down, in economic activity and performance and for a low dispersion of outcomes" (Streeck, 1997, p. 41). By contrast the UK innovation and production system is often characterised by a dependency on fickle capital markets, short-term business objectives and a more opportunistic (or entrepreneurial) approach to innovation (Roper, 1997; Dore et al., 1999). The consequence is a tendency towards more radical and sporadic innovation activity in the UK and a greater disparity in performance between leading edge and less well performing businesses (IBM/LBS, 1994). Both the UK and German innovation and production systems are strongly conditioned, however, by the wider social, legal and industrial relations systems within which they are set. Thus, DQP “is more than an individual firm's commercial strategy. It is conditional on an industrial order, or a social structure, that can only partly, provisionally and precariously exist on a voluntaristic-contractual basis. Where it is fully developed, it is the outcome of a collective 'cultural' choice mediated by and crystallised in a set of social institutions" (Streeck, 1992, p. 11).

The thesis of the present paper is that the UK and German sets of 'social institutions' represent different national responses to the fundamental uncertainty implicit in the process of innovation. For example, the incentive to innovate clearly depends on issues of appropriability, i.e. the firm's ability to protect and exploit the property rights arising as a result of its innovation. All firms have reason to fear the possible dissipation of such rents which may result from disclosure of new innovations by a research partner or subcontractor, especially when any new knowledge is tacit or embedded in individuals 
(Teece, 1988). Lane (1997) argues, for example, that the social context within the UK makes inter-firm network relationships based on mutual trust more difficult than in Germany. Other forms of legal and co-operative organisation clearly exist for collaborative research, however, and Kogut (1988), for instance, argues that joint ventures are an appropriate method of engaging in collaborative research where there is a high degree of uncertainty over specifying and monitoring performance ${ }^{1}$. Such formal arrangements for research collaboration may also go some way to reducing the transactions costs associated with problems of bargaining and incomplete contracts, and help attenuate the danger of 'hold-up' which may arise from transaction-specific investments under conditions of uncertainty (Klein, Crawford and Alchian, 1978; Williamson, 1979; Veugelers and Cassiman, 1998). Indeed, if as Lane (1997) suggests, inter-firm relationships are characterised by lower levels of trust than in Germany, UK firms may find legally defined forms of research collaboration more attractive than German plants both to protect property rights and reduce transaction costs. Any lack of trust in the UK may be particularly important in terms of innovation; by their very nature, research contracts tend to be highly incomplete and frequently involve substantial investment in both physical and human specific capital. Teece (1988) highlights the problem of 'lock-in' under these conditions: because of the tacit knowledge acquired by a contracting party in any external $R \& D$ arrangement, there may be very high transaction costs to incur should the other party seek to terminate the contract for reasons of underperformance. What is more, the highly uncertain nature of R\&D makes satisfactory contract completion difficult to define, possibly leading to a preference for market over hierarchy even where rent-seeking opportunism is not a major threat. In empirical terms the question is whether German and British firms adopt observably different responses to the property rights and transaction cost problems inherent in the innovation process, and

\footnotetext{
${ }^{1}$ Joint ventures involve mutual commitment of resources (financial and/or personnel), and provide joint ownership and control rights to the outcome of the research. Together, these two attributes give rise to a 'mutual hostage position' in which neither party has an incentive to shirk on the quantity or quality of their input to the venture (i.e. to act opportunistically) because such action will harm the residual value of the joint venture to the detriment of both parties. Unlike long-term contracts there is no need to specify ex ante the precise quantity and quality of inputs at every stage: "Instead, the initial commitments and rules of profit sharing are specified, along with administrative procedures for control and evaluation" (Kogut, 1988, p 321).
} 
whether these differences are manifest in the different ways in which firms from the two countries organise the innovation process internally and externally.

Our focus here is on certain key elements of the organisation of innovation; the ways in which knowledge is generated (e.g. by conducting R\&D) or gathered (through networking) by firms and then co-ordinated (through multifunctional groups) to produce innovations. Both innovation networks and multifunctional working, however, also feature significantly in other debates about organisational and industrial flexibility and moves towards leaner and more flexible production systems (e.g. Womack et al., 1991; Levine, 1995; Finegold and Wagner, 1998; Song et al., 1997). Freeman (1991, p. 501), for example, comments “... both empirical and theoretical research has long since demonstrated the importance for successful innovation of both external and internal networks of information and collaboration". The ability to adopt multifunctional working and inter-firm co-operation and collaboration also depends strongly on firms' willingness and internal capabilities (Young and Lan, 1997) and the way in which these are supported or undermined by firms' institutional setting. Herrigel (1996), for example, argues that the institutions which support DQP may be a barrier to the adoption by German firms of lean production concepts such as multifunctional working. In particular, it is suggested that the high degree of specialisation of German skilled workers and their 'culture' of disciplinary pride coupled with the narrow functional orientation of managers from different disciplines, may make it more difficult for German firms to establish multifunctional teams or integrated product development teams. Finegold and Wagner (1998) found that while more than two-thirds of German pump manufacturers had adopted some form of team-working and/or cellular manufacturing this tended to involve only a small proportion of all employees. Their evidence also suggested that German firms with more highly skilled workforces tended to find it more difficult to introduce multifunctional working because of potential loses in terms of job security and status by skilled individuals.

Offsetting these barriers to flexibility, Finegold and Wagner also suggest that: 
'While the strong role that technical skills play in the identity of German skilled workers appears to be a significant barrier for some companies in the adoption of multifunctional teams ... supporting this transition to this new organisation are: the strong general and applied skills that apprenticeships provide; the firm-based delivery of most training, meisters' combination of comprehensive technical, economic/business and pedagogical skills ... and the already relatively broad span of control in most German plants' (Finegold and Wagner, 1998, p. 479).

In the UK, by contrast the weakness of the industrial training system may have the somewhat ironic advantage of avoiding some of the barriers to adopting flexible work practices evident in German firms. More concern here relates to the potentially negative role of unions and long-standing doubts about levels of basic and intermediate skills and the quality of UK manufacturing management (e.g. Handy, 1988)

The contrasts between the UK and German innovation-production systems and their institutional supports suggest three questions. First, does the nature of product innovation activity in Germany accord with the incremental customisation suggested by the DQP paradigm, compared to the more episodic, ad hoc and, potentially, radical innovation which might be expected in the UK? Secondly, what does the evidence on the nature and extent of plants' innovation networking and collaboration suggest about the impact of firms' institutional context in the UK and Germany i.e. is there evidence that British and German firms adopt different mechanisms for dealing with the transaction cost and property rights issues inherent in innovation? And, finally, does the use of multifunctional groups by German firms in the innovation process suggest that the HSE is a barrier to or a facilitator of moves towards lean production?

\section{The Nature of Manufacturing Innovation Activity in the UK and Germany}

The data used here are taken from the Product Development Survey (PDS), a nationally representative survey of UK and German manufacturing plants' innovation activity (see Annex). The PDS relates to plants' innovation activity during the 1991 to 1993 period, at the beginning of the German recession of the mid-1990s, and a time when the UK 
economy was also experiencing a mild recession (Roper et al., 1996, pp 8-9)². The PDS is particularly well suited to addressing the questions raised in the previous section, partly because of its relatively large size (over 3000 responding plants), but mainly because of the very detailed data that it contains. Plant-level data are necessary in this research because our interest is less in the strategic determinants of innovation activity than in the detail of its organisation and implementation, issues which can only be satisfactorily explored at the level of the individual manufacturing facility. In particular, the PDS contains data not only on suitable measures of innovation output, the nature of this output, and the rationale for it, but also highly detailed information on the nature and extent of collaborative activity at each stage of the innovation process, and on the precise nature of multifunctional involvement in the innovation process.

The first question addressed is whether the observable innovation outputs of German and UK plants conform to the characterisation suggested by the DQP paradigm, that German innovative activity is likely to be incremental rather than radical, continual rather than episodic and more strongly oriented towards quality improvement than that in the UK. The PDS provides information on a number of relevant innovation output measures. For example, following from the DQP paradigm we might expect German plants' orientation towards continuous, incremental innovation to be evident in higher numbers of product changes per employee than that in UK plants, with the latter focussing, perhaps, on more episodic, radical product developments ${ }^{3}$. To test this argument, Table 1 gives the mean and median number of product changes per (100) employees made by UK and German plants over the 1991 to 1993 period. While the table clearly suggests the well-known tendency for innovation intensity (i.e. innovations per employee) to be higher among small plants (Acs and Audretsch, 1988), it provides no support for the argument that German plants were making higher numbers of product changes. Indeed, only among smaller plants was there any clear statistically significant difference in the number of product changes per employee, with higher levels among UK plants.

\footnotetext{
${ }^{2}$ Fieldwork for this study pre-dates that reported in Finegold and Wagner (1998) by 18-24 months. The intervening period was one of continuing weakness in the German economy with total employment falling by 10 per cent between 1989 and 1995 (Finegold and Wagner, 1998, p. 473)

${ }^{3}$ In the PDS a product change was defined as the 'introduction of any new or improved product'.
} 
Another aspect of the DQP paradigm is the implied continuity of German plants' innovation activity rather than the more episodic nature of innovation in the UK. In a single cross-sectional survey like the PDS it is difficult to observe this directly, but it should be true that for any time interval (e.g. 1991 to 1993) the proportion of innovating plants should be higher the more continuous is each plant's innovation activity. Table 2 therefore gives the proportion of UK and German manufacturing plants introducing new or improved products over the 1991 to 1993 period. Here, as in other previous studies of innovation (e.g. Kamien and Schwartz, 1982; Acs and Audretsch, 1988; Love et al, 1996) the PDS suggests that the proportion of innovating plants - and by implication the continuity of innovation activity - increases with plant size. Evidence for greater continuity of innovation activity in Germany rather than the UK, however, is confined to plants with 20-99 employees. For plants with more than 100 employees no statistically significant differences in the continuity of innovation could be identified.

Finally the DQP paradigm also suggests that we might expect qualitative differences in the nature of UK and German plants' innovation and product development activities. In particular, it suggests that German plants may place more emphasis on incremental product improvement, rather than the development of new products. The PDS provides two relevant indicators: first, information on the objectives of plants' product innovation activity; and, second evidence on the proportion of plants' sales which resulted from products newly introduced over the 1991 to 1993 period and from products which were being manufactured in 1991 but had subsequently been improved. In terms of the objectives of plants' innovation activities (Table 3), we find a broad similarity between UK and German plants, with both emphasising market share, quality enhancement and extending the product range (see also Roper et al., 1996, pp. 19-23). Where significant differences in plants' innovation objectives do exist they suggest that UK plants emphasise market entry, matching competitors and reducing product cost while German firms emphasise the development of green or environmentally friendly products (see also Roper, 1997; Love, 2001). In broad terms, this seems consistent with the DQP paradigm, with UK plants placing more emphasis on product cost and strategic market 
developments while German firms emphasise product quality-type issues. Looking at the outcomes from plants' innovation activity in terms of the origin of plants' sales we find more support for the DQP paradigm, with 20.2 per cent of the sales of German plants stemming from new products, significantly below the average level in the UK of 25.1 per cent. Conversely, 31 per cent of German plants' sales stemmed from improved products, significantly above the UK average of 27.7 per cent ${ }^{4}$.

In summary, we find no quantitative evidence that German plants' innovation activity either involves more product changes or is significantly more continuous than that of UK plants. Qualitative indicators, however, provide more support for the DQP paradigm with German firms emphasising quality improvement and deriving a significantly larger proportion of their sales from improved rather than new products. In sections 4 and 5 we explore how these innovation outputs are achieved, focussing first on collaboration and co-operation in the innovation process.

\section{Collaboration and Co-operation in the Innovation Process}

A diverse range of advantages may derive from collaboration and co-operation in the innovation process. Womack et al. (1991) in their discussion of lean production, for example, emphasise the potential role of collaboration as a means of accessing external expertise to allow concurrent development to take place and accelerate the product development process (e.g. Womack et al., 1991, pp. 109-110). Networks may also allow firms to take advantage of potential agglomeration and informational advantages in both high-tech (e.g. Saxenian, 1996; Shefer and Frenkel, 1998) and more traditional sectors (e.g. Perry, 1999, pp 89-100). It is not obvious, however, that the incremental nature of innovation within the DQP paradigm - and the innate disciplinary conservatism generated by the German skills training system - will necessarily increase the willingness or ability of German plants to involve outside organisations in their innovation activity. One reflection of this is the very different motivations that German and UK innovators

\footnotetext{
${ }^{4} \mathrm{~T}$-tests for equality of means are: for new products $\mathrm{t}=3.991, \rho=0.000$; improved products, $\mathrm{t}=-2.758$, $\rho=0.006$. Mann-Whitney tests were: for new products, $Z=-5.179, \rho=0.000$; for improved products, $Z=-$ $2.510, \rho=0.012$.
} 
have for collaboration in the innovation process (Table 4). In both countries the main motivation for innovation networking was to access external expertise. Significant differences existed, however, in the higher priority given by German plants to sharing the costs of innovation and risk reduction, and by UK plants to accelerating product development. One possibility is that these motivational differences may be reflected in the type and extent of UK and German plants' innovation networks. In particular, German plants may be networking more selectively with 'trusted' partners on a collaborative or quasi-hierarchy basis (Lane, 1997; Lane and Bachmann, 1996), while UK businesses may be less focussed on the riskiness of the innovation partnership itself which may be contractual or market based - and more focussed on the potential evaporation of any market opportunity.

The PDS provides details of innovating plants' external relationships during seven activities undertaken in the innovation process (Table 5). Each plant was asked to identify whether it involved other organisations in each innovation activity. In all activities in the innovation process there was evidence of intra-group and extra-group linkages among a minority of innovating plants, with the proportion of plants engaging in some form of collaboration varying from 9.8 per cent (German production engineering) to 34.2 per cent (German market research). Here again the data show clear statistical evidence of national variations. As might be expected - because of the much higher incidence of independent plants in the German sample ${ }^{5}$ - German innovators were markedly less likely to have intra-group linkages than UK plants in each of the innovation activities. With the exception of product testing and production engineering, however, German plants were more likely than their UK counterparts to have extra-group linkages in each innovation activity. More interesting, however, particularly given the attitudes to risk spreading and cost sharing outlined earlier, is the contractual basis for the extra-group collaborative relationships adopted in the two countries (Table 6). German plants were heavily involved in collaborative mechanisms with other firms, especially in the early stages of the innovation process, with a very limited use of formal sub-contract relationships:

\footnotetext{
${ }^{5} 85$ per cent of German plants were single establishment enterprises, compared with 52 per cent of UK plants.
} 
British plants also generally showed some preference for quasi-hierarchical, collaborative arrangements over sub-contracting, although this difference was much less marked than that for the German sample. Only in production engineering and product testing - both relatively standardised activities within the innovation process - were the contractual preferences of UK and German plants statistically similar. In other words, in the more risky activities within the innovation process, German plants were more likely to be working with independent partners in a relationship characterised by collaboration or trust; UK plants on the other hand were more likely to be working with other plants within their group and to have a sub-contract or legal aspect to the relationship. This evidence is consistent with that of Lane (1997) who argues that although German systems of rule-setting and regulation are highly formalised, this does not supersede more informal trust-based relationships. German manufacturing companies, it is argued, develop longer-term and closer relationships with their suppliers and customers than their British counterparts, which in turn encourages technological collaboration. By contrast, the British system of relations between firms does not encourage such behaviour. As a result:

"The establishment and maintenance of effective supplier relations entails higher transaction costs for the firms engaged at every stage of the relationship. The absence of reliable mechanisms of risk reduction makes British managers view long-term commitments with greater wariness than their German counterparts. Close relations of technical collaboration, based on mutual trust, seem to be regarded as less feasible in the British social context." (p. 214)

\section{Multifunctional groups}

Multifunctional groups have been argued to be an important facilitator of innovation (e.g. Rosenberg, 1982; Song et al., 1997) and their adoption is a key feature of lean production (e.g. Levine, 1995; Finegold and Wagner, 1998). Of particular importance in innovation are said to be feedbacks between internal functions such as engineering, marketing and R\&D (Bonnett, 1986; Gupta et al., 1986; Souder and Moenaert, 1992). The question posed by Finegold and Wagner (1998) and others, notably Herrigel (1996), is whether the institutions which support DQP would prove a barrier to the adoption of multifunctional 
working, or whether the stronger 'general and applied' skills of the German workforce would facilitate the adoption of more flexible production systems.

To investigate this type of question, the PDS asked innovating plants to indicate whether they involved staff from five major skill groups (scientists/technologists, engineers, designers, marketing and sales staff and skilled production workers) in each of seven activities in the product innovation process. Table 7 summarises these data, giving the proportion of innovative enterprises involving different numbers of the five skill groups identified. In each activity, significantly more plants in the UK were engaged in multifunctional working than in Germany, and there was also a tendency in the UK for more extensive multifunctional working than in Germany. Only 2-3 per cent of German plants involved more than three skill groups in each innovation activity, and virtually none involved more than four skill groups, while up to 13 per cent of UK plants involved five skill groups. Marked differences were also observed between the specific skill groups which UK and Germany plants involve in the different innovation activities (Table 8). Engineers dominate the product innovation process in German plants, but are no more likely to be involved in market research and strategy development than in the UK. Also notable is the much more common use of design staff throughout the product innovation process by UK plants - indeed, the German sample is notable for the relatively small input of design staff even in aspects of the process which might be considered design-intensive, such as prototype development. Equally marked is the dominance of marketing and sales staff in the initial stages of the product development process among innovating plants in the UK: in the earliest stage (identification of new products) over 85 per cent of responding plants from the UK indicated that there was marketing involvement, compared with 60 per cent in Germany. Only in the final stages of the process do these differences cease to be statistically significant, when marketing staff become the key personnel in both countries.

The clear implication from the PDS data is that at the time of the survey multifunctional working in product innovation had been more widely adopted in the UK than in Germany and, on average, a higher degree of inter-disciplinarity was evident in the UK. This 
suggests that at least at this period the adoption of flexible or lean production systems was proving more difficult for German firms than for those in the UK. In terms of the question posed by Finegold and Wagner (1998), therefore, this suggests that the social and institutional barriers to the adoption of multifunctional working in Germany were more than offsetting any advantages provided by higher general skill levels in Germany.

Differences in the functional groups involved in product innovation by UK and German firms also reflect the two countries' innovation objectives (Table 3). In the UK, the relatively high level of involvement of design and marketing staff emphasises the more market-led nature of UK plants' innovation which is consistent with their more marketoriented use of collaborative mechanisms highlighted earlier, and with their view of collaboration and/or networking principally as a means of speeding up the process of bringing new products to the market. (Roper, 1997; Love, 2001). By contrast, German plants' greater involvement of engineering staff suggests the more technocratic approach to innovation implicit in the DQP paradigm and German plants' stronger orientation towards product quality enhancement. This too is consistent with the findings discussed earlier, where the use of collaboration to reduce risk and share costs rather than accelerate innovation is consistent with an emphasis on core manufacturing and technological competencies rather than a more market-oriented attitude.

\section{Discussion and Conclusions}

We are now in a position to address the three questions posed at the outset. First, does the innovation activity of German and UK plants accord with the DQP paradigm? Although we can find no consistent quantitative evidence that German plants either make more (incremental) product changes or innovate more continuously than their UK counterparts, we do find clear differences in the objectives of UK and German plants' innovation activity and the composition of their sales. UK plants, for example, tend to emphasise market motives for innovation (e.g. entering new markets, matching competitors) while German plants placed more emphasis on product quality improvements. German plants also derived a higher proportion of their sales revenue from improved (rather than new) 
products than UK plants. Both of the latter results are consistent with the DQP paradigm emphasising the more incremental and less market focussed nature of German plants' innovation activity (Streeck, 1997).

The second question we considered was the impact of plants' institutional and social setting - and especially their responses to property rights and transaction cost issues - on inter-plant collaboration and co-operation in the innovation process. As with plants' innovation objectives we again identify significant differences between German and UK plants' reasons for inter-plant collaboration or co-operation. Consistent with their market focussed innovation objectives, UK plants emphasised increased speed to market as a key reason for inter-plant collaboration or co-operation. German plants on the other hand tended to emphasise the benefits of collaboration or co-operation in terms of risk and cost sharing. These results appear to reflect different managerial practices and attitudes. The innovation strategies of German manufacturing firms are more risk averse and less market responsive than those of UK businesses, reflected in the more managed and strategic German approach to product development. By contrast, British firms show a tendency for a more responsive and often time-critical approach to innovation and product development (Roper, 1997). Differences were also evident in the type of partners with which plants were engaged, and in the nature of the governance of those relationships. UK plants, for example, were much more likely to collaborate with other group companies than their German counterparts. Extra-group collaboration was more common in Germany, with German firms also showing a stronger preference for collaborative relationships rather than the sub-contracting approach which, although not common, was more prevalent among UK plants.

Lane (1997) argues that this contrast may reflect differences in the social and institutional context in the UK and Germany, with close relations based on mutual trust being regarded as less feasible in the former country. More specifically, however, the systematic variations in patterns of collaboration and co-operation between UK and German firms revealed by the PDS suggest differences in attitudes to the potential problems of property rights and transaction costs which may be experienced during the 
innovation process. The knowledge generated by R\&D activity is inherently 'leaky', and there is always the danger that firms which have not contributed to the research may freeride on its benefits. UK and German firms appear to have developed different methods of coping with this potential problem. One way of controlling free-rider problems is to involve potential competitors who could benefit from the research and development work being undertaken. German firms' emphasis on cost and risk-sharing and on the technical rather than market aspects of the innovation process is consistent with such an approach, and they clearly see their frequent use of collaboration as having low risk in terms of the dissipation of property rights. UK firms, on the other hand, display a more marketoriented approach which emphasises acceleration of the innovation process and accessing other firms' expertise. The UK response to the property rights problem involves less use of collaboration and more use of intra-group collaboration or co-operation, which attenuates the danger of dissipation and free-riding by keeping technology and tacit knowledge within the group. Subcontracting offers an alternative mechanism for organising externally conducted research but involves potential problems of maintaining intellectual property rights and contract compliance. As a result, sub-contracting relationships are less commonly used in innovation in both countries than internal or external collaboration. However, the systematic tendency for UK plants to make relatively more use of sub-contracting relationships suggests a greater willingness to view potential contractual problems as an acceptable trade-off for accelerated product development.

One possibility which must be considered is that these differences in collaborative activity arise because of differences in the sample of UK and German plants. Brouwer and Kleinknecht (1996), for example, argue that collaboration is to be found mainly among weak innovators, because these are the firms which are obliged to share the results of research with others, while Arvanitis and Hollenstein (1996) suggest that collaboration is principally a small firm phenomenon, because such firms lack the internal resources to engage in research and the resulting innovation on their own. Neither of these hypotheses is supported by the PDS data. The prevalence of innovation among German plants of all sizes and their extensive use of collaborative networks suggests that it is 
unlikely that only the weakly innovative employ this mechanism. Nor is collaboration the preserve of the smaller enterprise: for both the UK and Germany, there is no statistical difference between the levels of collaboration found between small (less than 100 employees) plants and large plants. The different national patterns are unlikely to be due simply to different incidences of 'weak' innovators, of small plants, or of other firm-level or plant-level factors; they are embedded firmly in the institutional framework of the countries of which they are part.

The third question is the extent to which UK and German plants have been able to adopt more flexible production systems, in particular multifunctional working. What we observe is that German plants are generally less likely to be engaged in multifunctional working in the innovation process, and where they are engaged in multifunctional working this is less strongly inter-disciplinary than that in the UK. This suggests - as hypothesised by Herrigel (1996) - that institutional barriers to the adoption of more flexible working practices in Germany may be more constraining than the generally lower level of general skills in the UK. The pattern of multifunctional working in the UK and Germany, however, also reflects plants' innovation objectives (and the underlying nature of innovation activity). German plants' innovation activity, for example, is strongly dominated by engineering staff whereas in the UK the more market oriented nature of innovation activity is reflected in a stronger involvement of design and marketing staff.

Taken together these results suggest a marked contrast in the impact on innovation organisation of the social and institutional context in UK and Germany. In Germany, institutional and social norms within the system of industrial relations mean that technical collaborations based on mutual trust are more feasible (Lane, 1997) but specialised skills and narrow functional orientation of management (Finegold and Wagner, 1998) make the adoption of more flexible internal systems such as multifunctional working more difficult. In the UK on the other hand, the more adversarial nature of Anglo-Saxon capitalism makes it more difficult to establish external collaborations based on mutual trust, but easier to adopt multifunctional working and achieve internal flexibility. 
Overall, therefore, the PDS suggests that there are national differences in the internal and external organisation of the innovation process which appear to be linked to different institutional structures in the UK and Germany, and specifically to different perceptions of the transaction costs and property rights issues underlying these institutional structures. The question this raises is whether these differences in the organisation of innovation have any serious implications for innovation outputs. If German firms are more adept at inter-firm collaboration, but UK firms are more able to benefit from multifunctional working and internal flexibility, what is the net effect of these influences on the overall innovativeness and competitiveness of manufacturing in the respective countries? Clearly an answer to this question is beyond the scope of the present paper, but there are intriguing pointers from recent research. Lane (1997), for example, finds that the technological collaboration fostered by close inter-firm relationships in Germany may have assisted in innovation development, at least of an incremental, non-radical nature. And, in an econometric analysis using PDS data, Love and Roper (2001) find that while intra-group collaboration has little effect on the number of product changes made in either country, it does have a positive effect on the commercial success of innovations in the UK. These results persist after taking account of a wide variety of plant-specific, industrial structure and regional effects on innovation, suggesting that the organisation of innovation does have a systematic effect on innovation performance. On the basis of this evidence, there is at least some suggestion that different institutional structures and the patterns of innovation organisation which they engender may have a systematic effect on the respective innovation performance of UK and German manufacturing. 
Table 1. Innovations per employee by plant size band

\begin{tabular}{|c|c|c|c|c|}
\hline & \multicolumn{3}{|c|}{ Employment Size Band } & \multirow[b]{2}{*}{ Total } \\
\hline & $20-99$ & $100-499$ & 500 plus & \\
\hline \multicolumn{5}{|c|}{ A. Mean Values } \\
\hline UK & 66.11 & 13.30 & 3.43 & 47.01 \\
\hline Germany & 24.30 & 17.68 & 4.97 & 20.95 \\
\hline \multicolumn{5}{|c|}{ B. Median Values } \\
\hline UK & 9.41 & 4.19 & 0.79 & 7.14 \\
\hline Germany & 7.69 & 3.74 & 1.40 & 5.51 \\
\hline
\end{tabular}

\section{Notes:}

1. Table relates to manufacturing plants with 20 or more employees. Survey responses were weighted to give representative results.

2. Sample sizes are as follows: UK; 20-99 employees, 403; 100-499 employees, 190; 500 plus employees, 30. Germany; 20-99 employees, 457; 100-499 employees, 218; 500 plus employees, 51 .

3. T test (Mann-Whitney $U$ test) results were as follows: $20-99$ employees, $t=3.854, \rho=$ $0.000(Z=-2.853, \rho=0.004) ; 100-499$ employees, $t=-0.563, \rho=0.574(Z=-0.756, \rho=$ $0.450) ; 500$ plus employees, $\mathrm{t}=-0.758, \rho=0.451(Z=-0.974, \rho=0.330)$; all plants, $\mathrm{t}=3.497, \rho=0.000(Z=-3.442, \rho=0.001)$.

\section{Source: PDS}


Table 2. Percentage of plants introducing new or improved products during a three year period

\begin{tabular}{lllll}
\hline & \multicolumn{3}{l}{ Employment Size Band } & \\
\cline { 2 - 4 } & $20-99$ & $100-499$ & 500 plus & Total \\
\hline \multirow{3}{*}{ UK } & 56.0 & 82.9 & 93.2 & 63.4 \\
Germany & 66.0 & 81.4 & 94.7 & 71.4 \\
& & & & \\
\hline
\end{tabular}

\section{Notes:}

1. Table relates to manufacturing plants with 20 or more employees. Survey responses were weighted to give representative results.

2. Sample sizes are as follows: UK; 20-99 employees, 810; 100-499 employees, 257; 500 plus employees, 35. Germany; 20-99 employees, 812; 100-499 employees, 301; 500 plus employees, 62 .

3. $\chi^{2}$ tests comparing the innovating proportion of plants in the UK and Germany were: 20 -99 employees, $\chi^{2}(1)=17.328, \rho=0.00 ; 100-499$ employees, $\chi^{2}(1)=0.208, \rho=$ 0.649 ; 500 plus employees, $\chi^{2}(1)=0.035, \rho=0.851$; all plants, $\chi^{2}(1)=16.495, \rho=$ 0.00 .

\section{Source: PDS}


Table 3: Objectives of product innovation of UK and German manufacturing plants (percentage saying each objective is 'important' or 'very important')

\begin{tabular}{cc}
\hline UK & Germany \\
$\%$ plants & $\%$ plants \\
\hline
\end{tabular}

\begin{tabular}{lll} 
A. Product-Related Objectives & & \\
Replace Existing Products & 45.89 & 45.04 \\
Extend the Product Range & 70.77 & 74.00 \\
Reduce Product Costs & 69.02 & 62.71 \\
Develop Green Products & 32.59 & 39.80 \\
Improve Product Quality & 81.21 & 78.69 \\
& & \\
B. Market-Related Objectives & & \\
Enter new Markets & 68.92 & 61.81 \\
Increase Market Share & 87.19 & 86.51 \\
Match Competitors & 60.59 & 49.27 \\
\hline
\end{tabular}

\section{Notes:}

1. Table relates to innovating plants with 20 or more employees. Survey responses were weighted to give representative results. Sample sizes are as follows: UK, 645;

Germany, 789.

2. T-tests for equality of means are as follows: Replace Existing Products, $\mathrm{t}=0.322, \rho=$ 0.748; Extend the Product Range, $\mathrm{t}=-1.385, \rho=0.166$; Reduce Product Costs, $\mathrm{t}=$ 2.533, $\rho=0.011$; Develop Green Products, $t==2.837, \rho=0.005$; Improve Product Quality, $\mathrm{t}=1.213, \rho=0.225$; Enter new Markets, $\mathrm{t}=2.862, \rho=0.004$; Increase Market Share, $\mathrm{t}=0.389, \rho=0.697$; Match Competitors, $\mathrm{t}=4.364, \rho=0.000$.

\section{Source: PDS}


Table 4. Percentage of networking plants indicating objectives of collaboration that were important or very important

\begin{tabular}{lcr}
\hline & UK & Germany \\
\hline & \% & \% \\
\hline Outsiders cost effective & 46.2 & 43.8 \\
Share innovation costs & 19.1 & 33.7 \\
Reduce innovation risk & 21.8 & 32.7 \\
Access to technology & 56.8 & 56.3 \\
Access to expertise & 76.5 & 72.5 \\
Faster Development & 63.1 & 51.7 \\
Meet regulatory requirements & 31.1 & 28.1
\end{tabular}

\section{Notes:}

1. Table relates to manufacturing plants with 20 or more employees. Survey responses were weighted to give representative results. Sample sizes are as follows: UK, 337; Germany, 391.

2. $\chi^{2}$ tests comparing objectives of collaboration: Outsiders more cost effective $\left(\chi^{2}(1)\right.$ $=0.478, \rho=0.489$ ); Share innovation costs $\left(\chi^{2}(1)=19.025, \rho=0.000\right)$; Reduce innovation risk $\left(\chi^{2}(1)=10.738, \rho=0.001\right)$; Access to technology $\left(\chi^{2}(1)=0.014, \rho=\right.$ $0.904)$; Access to expertise $\left(\chi^{2}(1)=1.639, \rho=0.200\right)$; Faster Development $\left(\chi^{2}(1)\right.$ $=9.551, \rho=0.002)$; Meet regulatory requirements $\left(\chi^{2}(1)=0.731, \rho=0.392\right)$.

\section{Source: PDS}


Table 5. Collaborative mechanism in the innovation process (all plants)

\begin{tabular}{|c|c|c|c|c|c|}
\hline & Total & $\begin{array}{l}\text { Intra- } \\
\text { Group } \\
\text { Only } \\
(2)\end{array}$ & $\begin{array}{l}\text { Extra- } \\
\text { Group } \\
\text { (3) }\end{array}$ & $\begin{array}{c}\text { Extra- } \\
\text { Group } \\
\text { Only } \\
(4)\end{array}$ & $\begin{array}{c}\text { Intra- and } \\
\text { Extra- } \\
\text { Group } \\
\text { (5) }\end{array}$ \\
\hline \multicolumn{6}{|l|}{ UK } \\
\hline Identifying New Products & 26.1 & 12.2 & 14 & 6.6 & 7.4 \\
\hline Prototype development & 30.5 & 11.0 & 19.5 & 10.6 & 8.9 \\
\hline Final design/development & 26.3 & 8.8 & 17.4 & 9.7 & 7.7 \\
\hline Product Testing & 30.5 & 10.6 & 19.9 & 11.9 & 8.0 \\
\hline Production Engineering & 21.0 & 8.3 & 12.7 & 6.0 & 6.7 \\
\hline Market Research & 29.5 & 12.5 & 17.0 & 10.3 & 6.7 \\
\hline $\begin{array}{l}\text { Developing Marketing } \\
\text { Strategy }\end{array}$ & 24.9 & 12.8 & 12.0 & 8.4 & 3.6 \\
\hline \multicolumn{6}{|l|}{ Germany } \\
\hline Identifying New Products & 26.4 & 2.6 & 23.8 & 22.2 & 1.6 \\
\hline Prototype development & 28.3 & 2.8 & 25.6 & 23.5 & 2.1 \\
\hline Final design/development & 25.5 & 3.8 & 21.6 & 19.4 & 2.2 \\
\hline Product Testing & 14.1 & 2.3 & 11.8 & 10.6 & 1.2 \\
\hline Production Engineering & 9.8 & 3.2 & 6.6 & 6.4 & 0.2 \\
\hline Market Research & 34.2 & 3.8 & 30.3 & 29.9 & 0.4 \\
\hline $\begin{array}{l}\text { Developing Marketing } \\
\text { Strategy }\end{array}$ & 20.4 & 4.1 & 16.4 & 15.9 & 0.5 \\
\hline
\end{tabular}

\section{Notes:}

1. Table relates to manufacturing plants with 20 or more employees which introduced new or improved products over a three-year period. Survey responses were weighted to give representative results. Sample sizes are: UK, 674; Germany, 777.

2. $\chi^{2}$ tests comparing forms of collaboration in the UK and Germany were: Identifying New Products, $\chi^{2}(3)=162.35, \rho=0.000$; Prototype development, $\chi^{2}(3)=118.42, \rho$ $=0.000 ;$ Final design/development, $\chi^{2}(3)=82.444, \rho=0.000$; Product Testing, $\chi^{2}(3)$ $=96.870, \rho=0.000$; Production Engineering, $\chi^{2}(3)=51.483, \rho=0.000$; Market Research, $\chi^{2}(3)=140.41, \rho=0.000$; Developing Marketing Strategy, $\chi^{2}(3)=78.756$, $\rho=0.000$.

Source: PDS 
Table 6. Collaboration and sub-contracting as alternative forms of extra-group innovation networking

\begin{tabular}{lllll}
\hline & UK & & Germany \\
\hline & $\begin{array}{l}\text { Collabor- } \\
\text { ation } \\
\%\end{array}$ & $\begin{array}{l}\text { Sub- } \\
\text { Contract } \\
\%\end{array}$ & $\begin{array}{l}\text { Collabor- } \\
\text { ation } \\
\%\end{array}$ & $\begin{array}{l}\text { Sub- } \\
\text { Contract } \\
\%\end{array}$ \\
\hline Identifying New Products & 86.6 & 13.4 & 97.0 & 3.0 \\
Prototype development & 61.5 & 38.5 & 89.1 & 10.9 \\
Final design/development & 83.6 & 16.4 & 92.1 & 7.9 \\
$\begin{array}{l}\text { Product Testing } \\
\text { Production Engineering }\end{array}$ & 71.1 & 28.9 & 79.3 & 20.7 \\
$\begin{array}{l}\text { Market Research } \\
\text { Developing Marketing Strategy }\end{array}$ & 74.4 & 25.6 & 78.5 & 21.5 \\
& 62.4 & 37.6 & 86.9 & 13.1 \\
\hline
\end{tabular}

\section{Notes:}

1. Table relates to manufacturing plants with 20 or more employees conducting extragroup networking. Survey responses were weighted to give representative results. Sample sizes are: UK, 55-104; Germany, 82-295.

2. $\chi^{2}$ tests comparing forms of extra-group networking in the UK and Germany were: Identifying New Products, $\chi^{2}(1)=12.455, \rho=0.000$; Prototype development, $\chi^{2}(1)=$ 39.67, $\rho=0.000$; Final design/development, $\chi^{2}(1)=6.149, \rho=0.013$; Product Testing, $\chi^{2}(1)=2.053, \rho=0.152$; Production Engineering, $\chi^{2}(1)=0.226, \rho=0.635$; Market Research, $\chi^{2}(1)=31.952, \rho=0.000$; Developing Marketing Strategy, $\chi^{2}(1)=$ 22.597, $\rho=0.000$.

\section{Source: PDS}


Table 7: Extent of multifunctional working in product innovation: percentage of innovating plants

\begin{tabular}{lccccc}
\hline & \multicolumn{5}{c}{ Number of skill groups involved: } \\
\cline { 2 - 6 } & 1 & 2 & 3 & 4 & 5 \\
\hline & & & & & \\
A. UK & & & & & \\
Identifying New Products & 25.7 & 31.4 & 19.6 & 12.0 & 11.4 \\
Prototype development & 23.6 & 25.4 & 25.5 & 14.0 & 11.5 \\
Final design/development & 22.3 & 24.4 & 25.3 & 15.1 & 13.0 \\
Product Testing & 37.0 & 32.1 & 15.8 & 6.1 & 9.0 \\
Production Engineering & 33.4 & 31.5 & 20.5 & 7.2 & 7.4 \\
Market Research & 65.1 & 21.7 & 5.0 & 1.7 & 6.5 \\
Developing Marketing & 60.8 & 19.7 & 7.5 & 6.3 & 5.6 \\
Strategy & & & & & \\
& & & & & \\
B. Germany & & & & & \\
Identifying New Products & 51.0 & 31.6 & 15.0 & 2.3 & 0.1 \\
Prototype development & 52.5 & 30.0 & 15.9 & 1.5 & 0.1 \\
Final design/development & 47.4 & 30.3 & 18.8 & 2.9 & 0.7 \\
Product Testing & 57.8 & 34.3 & 6.1 & 1.8 & 0.1 \\
Production Engineering & 71.5 & 27.1 & 1.4 & & \\
Market Research & 83.9 & 14.0 & 2.1 & & \\
Developing Marketing & 83.4 & 15.0 & 1.5 & 0.1 & \\
Strategy & & & & & \\
& & & & & \\
\hline
\end{tabular}

\section{Notes}

1. Table relates to innovating plants with 20 or more employees. Five skill groups were identified: scientists or technologists, engineers, designers, marketing/sales staff, skilled production staff. Survey responses were weighted to give representative results. Sample sizes are as follows: UK, 621; Germany, 762.

2. $\chi^{2}$ tests comparing proportions of plants involving different numbers of skill groups a in each element of their innovation activity: Identifying New Products $\chi^{2}(4)=198.9, \rho$ $=0.000$; Prototype development $\chi^{2}(4)=249.6, \rho=0.000$; Final design/development $\chi^{2}(4)=213.7, \rho=0.000$; Product Testing $\chi^{2}(4)=145.9, \rho=0.000$; Production Engineering $\chi^{2}(4)=331.5, \rho=0.000$; Market Research $\chi^{2}(4)=96.5, \rho=0.000$; Developing Marketing Strategy $\chi^{2}(4)=145.4, \rho=0.000$

Source: PDS 
Table 8. Percentage of innovators involving staff at each stage of the production process (all plants)

\begin{tabular}{lccccc}
\hline & Scientists & Engineers & Designers & $\begin{array}{c}\text { Marketing/ } \\
\text { Sales }\end{array}$ & $\begin{array}{c}\text { Production } \\
\text { Staff }\end{array}$ \\
\hline UK & & & & & \\
Identifying New Products & 35.6 & 39.1 & 40.7 & 85.7 & 45.3 \\
Prototype development & 35.9 & 51.7 & 51.7 & 42.4 & 65.8 \\
Final design/development & 30.8 & 50.9 & 53.9 & 53.5 & 64.1 \\
Product Testing & 32.4 & 41.5 & 33.6 & 42.3 & 49.0 \\
Production Engineering & 23.0 & 60.2 & 26.8 & 11.6 & 68.3 \\
Market Research & 16.2 & 14.6 & 19.0 & 89.5 & 0.90 \\
Developing Marketing & 17.3 & 21.0 & 19.7 & 91.5 & 14.5 \\
Strategy & & & & & \\
& & & & & \\
Germany & & & & & \\
Identifying New Products & 8.7 & 61.9 & 12.7 & 60.3 & 25.2 \\
Prototype development & 8.0 & 69.7 & 19.9 & 16.5 & 52.5 \\
Final design/development & 4.5 & 65.4 & 32.7 & 33.6 & 43.0 \\
Product Testing & 6.4 & 59.1 & 3.6 & 15.6 & 67.5 \\
Production Engineering & 1.0 & 55.9 & 0.3 & 7.3 & 65.4 \\
Market Research & 4.2 & 14.5 & 3.3 & 92.9 & 3.3 \\
Developing Marketing & 2.9 & 17.1 & 2.0 & 92.9 & 3.3 \\
Strategy & & & & & \\
\hline
\end{tabular}

\section{Notes:}

1. Table relates to innovating plants with 20 or more employees. Survey responses were weighted to give representative results. Sample sizes are as follows: UK, 680; Germany, 753.

2. All values were significantly different at the 5 per cent level between the UK and Germany except: engineers in production engineering $\left(\chi^{2}(1)=2.733, \rho=0.098\right)$, production staff in production engineering $\left(\chi^{2}(1)=1.383, \rho=0.240\right)$, engineers involved in market research $\left(\chi^{2}(1)=0.003, \rho=0.957\right)$, engineers involved in marketing strategy $\left(\chi^{2}(1)=3.325, \rho=0.068\right)$, marketing or sales staff involved in marketing strategy $\left(\chi^{2}(1)=1.076, \rho=0.300\right)$.

\section{Source: PDS}




\section{Annex: The Product Development Survey}

The Product Development Survey (PDS) was a postal survey of manufacturing establishments in the UK and Germany conducted between October 1994 and April 1995. The survey related to plants' innovation activities during the 1991 to 1993 period. The main purpose of the survey was to discover the extent of product innovation and development at each plant, and develop indicators of how this development was organised both internally and externally. In each country the sample was structured to allow size-band, regional and industry sector comparisons. Overall response rates of 20.6 per cent in the UK (1722 responses) and 25.1 per cent in Germany (1374 responses) were achieved. Prior to the analysis survey responses were weighted to allow for sample structuring and differential response rates. Weights for each industry/size-band cell were constructed by comparing sample responses and the 1993 target population of manufacturing firms in each country. Full details of the sampling, survey and weighting processes can be found in Roper et al (1996), pp. 61-66. 


\section{References}

Acs, Z. J. and Audretsch, D. B. 1988. Innovation in large and small firms: an empirical analysis, American Economic Review, vol. 78, 678-90

Arvanitis, S. and Hollenstein, H.1996. Industrial innovation in Switzerland: a modelbased analysis with survey data, in Kleinknecht, A. (ed), Determinants of Innovation the Message from New Indicators, London and Basingstoke, Macmillan

Audretsch, D. B. 1995. Innovation and Industry Evolution, Cambridge, Mass., MIT Press

Bonnett, D. 1986. Nature of the R\&D/marketing co-operation in the design of technologically advanced new industrial products, $R \& D$ Management, vol. 16, $117-26$

Braczyk, H.-J., Cooke, P. and Heidenreich, M. 1998. Regional Innovation Systems, London, UCL Press

Brouwer, E. and Kleinknecht, A. 1996. Determinants of innovation: a microeconometric analysis of three alternative innovation output indicators, in Kleinknecht, A. (ed) Determinants of Innovation the Message from New Indicators, London and Basingstoke, Macmillan

Culpepper, P. D. 1999. The future of the high-skill equilibrium in Germany, Oxford Review of Economic Policy, vol 15, 43-59

Dore, R., Lazonick, W. and O'Sullivan, M. 1999. Varieties of capitalism in the twentieth century, Oxford Review of Economic Policy, vol 15, 102-120 
Finegold, D. and Wagner, K. 1998. The search for flexibility: skills and workplace innovation in the German pump industry', British Journal of Industrial Relations, vol. $36,469-487$

Finegold, D. and Soskice, D. 1988. The failure of training in Britain: analysis and prescription, Oxford Review of Economic Policy, vol. 4, 21-53

Freeman, C. 1991. Networks of innovators: a synthesis of research issues, Research Policy, vol. 20, 499-514

Grabher, G. and Stark, D. 1997. Organising diversity: evolutionary theory, network analysis and post-socialism”, Regional Studies, vol. 31, 533-544

Gupta, A. K., Raj, S. P. and Wilemon, D. 1986. A model for studying R\&D-marketing interface in the product innovation process, Journal of Marketing, vol. 50, 7-18

Handy, C. 1988. Making Managers, London, Pitman

Heidenreich, M. and Krauss, G. 1998. The Baden-Wurttemberg production and innovation regime: past successes and new challenges, in Braczyk, H.-J., Cooke, P. and Heidenreich, M. (eds), Regional Innovation Systems, London, UCL Press

Herrigel, G. 1996. Crisis in German decentralised production, European Urban and Regional Studies, vol. 3, 33-52

IBM and LBS. 1994. Made in Europe: A Four Nations Best Practice Study, London.

Kamien, M. and Schwartz, N. 1982. Market Structure and Innovation, Cambridge, Cambridge University Press 
Keck, O. 1993. The national system for technical innovation in Germany, in Nelson, R. (ed), National Innovation Systems, Oxford, Oxford University Press

Klein, B., Crawford, A. and Alchian, A. 1978. Vertical integration, appropriable rents and the competitive contracting process, Journal of Law and Economics, vol. 21, 297-326

Kogut, B. 1988. Joint ventures: theoretical and empirical perspectives, Strategic Management Journal, vol. 9, 319-32

Koschatzky, K., Kulicke, M. and Zenker, A. 2001. Innovation Networks: Concepts and Challenges in the European Perspective, Heidelberg, Physica-Verlag

Lane, C. 1997. The social regulation of inter-firm relations in Britain and Germany: market rules, legal norms and technical standards, Cambridge Journal of Economics, vol. 21, 197-215

Lane, C. and Bachmann, R. 1996. The social constitution of trust: supplier relations in Britain and Germany, Organization Studies, vol. 17, 365-95

Levine, D. 1995. Re-inventing the Workplace, Washington, Brookings Institute

Love, J. H. 2001. Patterns of networking in the innovation process: a comparative study of the UK, Germany and Ireland, in Jones, O., Conway, S. and Steward F. (eds), Social Interaction and Organisational Change: Aston Perspectives on Innovation Networks, London, Imperial College Press

Love, J. H. and Roper, S. 1999. The determinants of innovation: R\&D, technology transfer and networking effects, Review of Industrial Organization, vol. 15, 43-64. 
Love, J. H. and Roper, S. 2001. Location and network effects on innovation success: evidence for UK, German and Irish manufacturing plants, Research Policy, vol, 30, 643-61.

Mansfield, E. 1984. Comment on using linked patent and R\&D data to measure interindustry technology flows, in Griliches, Z. (ed), $R \& D$, Patents and Productivity, Chicago, University of Chicago Press

Morgan, K. 1997. The learning region: institutions, innovation and regional renewal, Regional Studies, vol. 31, 491-503

Nelson, R.R. 1993. National Innovation Systems, New York, Oxford University Press

Perry, M. 1999. Small Firms and Network Economies, London, Routledge

Roper, S. 1997. Product innovation and small business growth: a comparison of the strategies of German, UK and Irish companies, Small Business Economics, vol. 9, $523-37$

Roper. S., Ashcroft, B., Love, J. H., Dunlop, S., Hofmann, H. and Vogler-Ludwig, K. 1996. Product Innovation and Development in UK, German and Irish Manufacturing, Northern Ireland Economic Research Centre/Fraser of Allander Institute, University of Strathclyde

Roper, S., Love, J. H., Ashcroft, B. and Dunlop, S. 2000. Industry and location effects on plants' innovation propensity, Annals of Regional Science, vol.34, 489-502

Rosenberg, N. 1982. Inside the Black Box: Technology and Economics, Cambridge, Cambridge University Press 
Saxenian, A. 1996 Regional Advantage - Culture and Competition in Silicon Valley and Route 128, Cambridge, Mass., Harvard University Press

Shefer, D. and Frenkel, A. 1998. Local milieu and innovations: some empirical results, Annals of Regional Science, vol. 32, 185-200

Song, X. M., Montoya-Weiss, M. M. and Schmidt, J. B. 1997. Antecedents and consequences of cross functional co-operation: a comparison of $R \& D$, manufacturing and marketing perspectives, Journal of Product Innovation Management, vol. 14, 35-47

Soskice, D. 1997. German technology policy, innovation, and national institutional frameworks, Industry and Innovation, vol. 4, 75-96

Souder, W. E. and Moenaert, R. K. 1992. Integrating marketing and R\&D project personnel within innovation projects: an information uncertainty model, Journal of Management Studies, vol. 29, 485-502

Streeck, W. 1989. Skills and the limits of neo-liberalism: the enterprise of the future as a place of learning, Work, Employment and Society, vol. 3, 89-104

Streeck, W. 1992. Social Institutions and Economic Performance: Studies of Industrial Relations in Advanced Capitalist Economies, London, Sage

Streeck, W. 1997. German capitalism: does it exist? Can it survive?, in Crouch, C. and Streeck, W. (eds), The Political Economy of Modern Capitalism, London, Sage

Teece, D. 1988. Technological change and the nature of the firm, in Dosi G. et al (eds), Technical Change and Economic Theory, London, Pinter 
Veugelers, R. and Cassiman, B. 1999. Make and buy in innovation strategies: evidence from Belgian manufacturing firms, Research Policy, vol. 28, 63-80

Walker, W. 1993. National innovation systems: Britain, in Nelson, R. R. (ed), National Innovation Systems: A Comparative Analysis, Oxford, Oxford University Press

Williamson, O. E. 1979. Transaction cost economics: the governance of contractual relations, Journal of Law and Economics, vol. 22, 3-61

Womack, J. P., Jones, D.T. and Roos, D. 1991. The Machine that Changed the World, New York, Harper Perennial

Young, S. and Lan, P. 1997. Technology transfer to China through foreign direct investment, Regional Studies, vol. 31, 669-80 